\title{
Architecture of Consumption: Shopping Centres in Soviet Lithuania from the 1960 s to 1980
}

vol. 10, 2021, 2, pp. 86-114

Brigita Tranavičiūté*

DOI: https://doi.org/10.33542/CAH2021-2-04

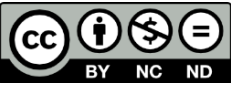

The construction of Soviet shopping centres that started in the 1960s marked a new stage in the consumption possibilities of Soviet society with the environments of consumption playing an important role. The main objective of this article is stated as follows: to analyse, following the LSSR (Lithuanian Soviet Socialist Republic) case, what the idea of Soviet shopping centres and its realization in the LSSR was and to ascertain how the Soviet authorities used the shopping centres for the development of consumption in Soviet society employing the advertising of shopping centres and the contraposition between socialism and capitalism. To achieve the research objective, the main method used was to analyse the published and unpublished sources that reflect the process of the appearance of Soviet shopping centres. The research demonstrates that the idea of Soviet shopping centres was not an original product of the Soviet system. Some aspects of their construction and composition were copied and there were attempts to implement them using Western practices.

Keywords: Shopping centres. Architecture of consumption. Soviet society. Urban. Advertising.

\section{Introduction}

After World War II, the commercial system of the Lithuanian Soviet Socialist Republic (LSSR) was restructured according to the Soviet model - eliminating private trade, the shops operating at that time were nationalized and merged into one single chain with a centralized delivery of goods and regulation of prices. In the 1950s, following the example of Moscow and other major cities of the USSR, department stores, specialized food stores and consumer goods shops were founded in the LSSR, mostly operating in buildings with former commercial functions.

In the LSSR, the main type of Soviet shops, that is department stores, were prevailing by the beginning of the 1960 s when the implementation of the new urban development plans, including the construction of commercial and service buildings, was launched. A hypothesis may be made that with the aforesaid urban development process, the realization of the key development ideas of Soviet shopping centres was started, confirming the consumption needs of Soviet society and the importance of the environment of consumption. However along with the direct functions assigned by Soviet propaganda to this type of commercial buildings, that is to provide goods and services in one place, propaganda activities targeted at the formation of the consumption habits of Soviet society defined by consumption criteria were also delegated. Taking into account the abovesaid, the consumption habits of Soviet society were expected to feature the rationality declared by Soviet propaganda, thereby avoiding overconsumption.

The expansion of the idea of Soviet shopping centres pushed for new architectural solutions able to contribute to the development of the rationality-based Soviet culture

Dr Brigita Tranavičiūtè, Institute of Architecture and Construction, Kaunas University of Technology, Kaunas, Lithuania; brigita.tranaviciute@ktu.lt; ORCID iD: 0000-0002-5015-2702 
of consumption while at the same time justifying its unique character. The new types of building were supposed to become a kind of architecture of consumption, where the shopping centre spaces and content would dictate consumption criteria to society and develop the consumption habits of Soviet society. This process marked a new developmental stage in Soviet shopping spaces and public consumption; however, there are in fact no research studies available investigating this stage.

Referring to the abovesaid, the main objective of this article is stated as follows: to analyse, following the LSSR case, what the idea of Soviet shopping centres and its realization in the LSSR was and to ascertain how the Soviet authorities used the shopping centres for the development of consumption in Soviet society employing the advertising of shopping centres and the contraposition between socialism and capitalism. To achieve the objective, efforts are made to answer a range of problematic questions: how the idea of Soviet shopping centres was influenced by the developmental trends of Western shopping centres; how the idea of Soviet shopping centres was developed in the LSSR; and what tools were applied in the formation of the consumption habits of Soviet society based on the consumption criteria imposed by propaganda and employing the advertising capacity of shopping centres.

\section{Research sources and methodology}

In order to meet the main objective of the research study, published and unpublished sources were analysed. One of the major portions of the sources represents published references, that is Soviet period literature of a general character intended for architecture, trade and advertising professionals of the entire USSR. In the USSR, a great range of publications was published dedicated to architecture and design experts and dealing with the issues of urban planning, architecture and the designing of individual projects. ${ }^{1}$ Some publications also included evaluations of the construction works of foreign shopping centres, and their reflections may be found in the realization of the idea of Soviet shopping centres.

The second portion of published sources contains publications dedicated to architects, designers and advertising copywriters of the LSSR. Architecture issues of the LSSR were discussed in Statyba ir architektūra, ${ }^{2}$ a specialized magazine intended for architects that published articles on shopping centres along with papers and responses by the very architects who had designed the shopping centres under consideration. The theory of the development of advertising for the commercial buildings of the LSSR was shaped in special trader-focused publications, whereas architects, decorators and other professionals responsible for advertising activities were encouraged to put out articles in the press discussing the appropriate use of advertising tools and taking into account the propaganda requirements. The most systematic attempts to shape the theory of the advertising development of the commercial buildings of the LSSR are found in Kooperatininkas, ${ }^{3}$ the publication of the Union of Lithuanian Consumer Cooperatives (Lietkoopsajunga), dealing with a range of trade-related issues.

1 BUTYAGIN, Planirovka iblogoustroystva. ADAMOVICH et al. Arkhitekturnoye proyektirovaniye obshchestvennykh. SHVIDKOVSKIY, Gradostroitel'naya kul'tura sotsialisticheskoy. VASIL'YEV - PLATONOV, Gradostroitel'naya praktika. URBAKH, Torgovyye zdaniya. URBAKH, Obshchestvenno torgovyye tsentry. ORLOV et al. Magaziny. SNARSKIY, Reklama vokrug nas, 3.

2 Statyba ir architektūra, 1958-2018.

3 Kooperatininkas, 1958-1995. 
Another portion of the investigated material contains unpublished sources available in the funds of the Ministry of Commerce of the LSSR (R-772) and the State Committee on Construction Affairs of the LSSR (R-45), stored in the Lithuanian Central State Archives (LCSA). Issues regarding shopping centres of particular cities and towns were analysed using the materials available in the funds of the Urban Planning and Design Institute (1036) and the Urban Development Department of the Vilnius City Council (1011), stored in the Vilnius Regional State Archives (VRSA). Some issues related to advertising design of shopping centres were investigated referring to the materials available in the fund of the Executive Committee of the Kaunas City Council of People's Deputies (R-292) stored at Kaunas Regional State Archives (KRSA).

\section{Literature review}

The vast majority of the studies carried out in relation to the development of shopping centres cover the problematic issues typical of the evolution of Western shopping centres. While analysing Western shopping malls, Richard W. Longstreth noticed that regional shopping centres had appeared in city suburbs after World War II. They became the opposite to the concentrated retail networks in the city centres. The regional shopping centres were built quite far from the residential areas and they had large car parks. ${ }^{4}$ According to Thomas W. Hanchett, US shopping centres took off when cars had become the norm in daily life and businessmen saw the potential of suburban stores with parking by the door. ${ }^{5}$ That idea was reflected in the Southdale Center in Edina, near Minneapolis, that was built in 1954-1956 under the "Gruen" project. It marked a new paradigm in the American consumer culture - shopping was moved further from the city centre. ${ }^{6}$

Some authors have broadly analysed the input of Victor Gruen into the idea of the development of shopping centres and its implementation process. ${ }^{7}$ David Smiley draws attention to the concept of the Gruen shopping centre as a place of social attraction, where social and cultural activities could be concentrated, in addition to trade. ${ }^{8}$ Alex Wall has a similar opinion. According to him, the shopping centres designed by Gruen merged the objectives of private trade and public city life because they had to perform not only the function of commercial, but also cultural space. ${ }^{9}$

A broad analysis is available on the implementation of Victor Gruen's concept of shopping centres inside the US ${ }^{10}$ and on its adaptation outside the US, ${ }^{11}$ on the development character of shopping centres located in regions, suburbs and urban centres, ${ }^{12}$ on shopping centres as a precondition of consumer society's formation and the "Americanization" of consumption. ${ }^{13}$

\footnotetext{
LONGSTRETH, City Centre, 14.

HANCHETT, U.S. Tax, 1083.

LONGSTRETH, Southdale Centre, 43.

HARDWICK, Mall Maker. SMILEY, Pedestrian Modern. WALL, Victor Gruen.

SMILEY, Pedestrian Modern.

WALL, Victor Gruen.

10 MENNEL, Victor Gruen and the Construction, 116-150. HARDWICK, Mall Maker. MALHEREK, Shopping Malls, 79-98.

11 GREGG, Conceptualizing the Pedestrian, 551-577. GOSSEYE, Collectivity and the Post-war, 245-264.

12 GILLETTE, The Evolution of the Planned, 449-460. MACK, Hello, consumer! Skärholmen, 122-137.

13 JESSEN - LANGER, Transformations of Retailing. DE GRAZIA, Irresistible Empire: America's.
} 
A process of tracking the developmental history of Soviet shopping centres reveals rather fragmented research into the problem in the aforesaid regard. Actually, the greatest focus thus far has been on the problematic issues related to the consumption of Soviet society, the preconditions of consumption formation and deficit. ${ }^{14}$ The consumption dimension of Soviet society has been broadly investigated by comparative means regarding the attitudes of the capitalist and socialist systems, targeting an analysis covering the competition between the political systems and its influence on consumption development. An especially great proportion of research studies focuses on the analysis ${ }^{15}$ of Western influences on the formation of Soviet society as well as on the investigation of Soviet consumption attributes such as rationality, asceticism etc. ${ }^{16}$

The topic of shopping centres under socialism has also been explored from the outlook of the socialist European countries. Sanja Matijević Barčot and Ana Grić analyse the emergence of shopping centres in Socialist Croatia, discussing the growth preconditions of consumer culture and the role of the architecture of shopping centres as a dimension in the formation of modern society in Socialist Yugoslavia. ${ }^{17}$

The Soviet shopping centre as a building becomes a subject of research in the analysis of the development trends of Soviet residential areas. Architectural features of the shopping centres located in mikrorayons (or microdistricts) of the LSSR are explored by Marija Drèmaitè. According to the author, centres in mikrorayons were considered the major component of the Soviet consumption service chain. ${ }^{18}$ As explained by Matas Šiupšinskas and Epp Lankots, the theoretical model of a tiered system of public services and the major ideological mission of mikrorayon centres were targeted at the promotion of consumption and individual behaviour within the boundaries of collectivism. ${ }^{19}$ The positions of Drèmaitè along with Šiupšinskas and Lankots linking shopping centres with mikrorayons, however, do not provide a complete picture of the situation. The present article will reveal that the system of Soviet shopping centres was considerably more sophisticated and was focused on the public services of the residents not only of mikrorayons, but also of residential areas or even of the entire city.

In historiography, the links between Scandinavian and Soviet residential area planning and shopping centre architecture are observed, they having determined the transformation of shopping centres into the hubs of new residential areas with good possibilities to reach them by public transport. ${ }^{20}$ The urban model ABC (Arbete, Bostad, Centrum), having originated in Sweden in the 1950 s and connecting the "multifunctional satellite city" with workplaces and a local centre, is considered one of the influences made on the development of the idea of Soviet shopping centres. ${ }^{21}$ In historiography, a rather broad analysis on the concepts of socialist residential areas

14 FITZPATRICK, Everyday Stalinism. CHERNYSHOVA, Soviet Consumer Culture. REID, Cold War in the Kitchen, 211-252. ZAKHAROVA, How and What to Consume, 85-112.

15 REID, Cold War in the Kitchen, 211-252. DE GRAZIA, Irresistible Empire, 456-460. ZAKHAROVA, Dior in Moscow, 95-120. GORSUCH, From Iron Curtain, 153-171. PEACOCK, Cold War Consumption, 83-98.

16 WEITZMAN, Soviet Long-Term, 305-321. BUCHLI, An Archaeology. GUROVA, Ideology of Consumption, 95. HESLLER, A Social History, 8.

17 MATIJEVIĆ BARČOT - GRIĆ, Shopping as a Part, 155-167.

18 DRÉMAITĖ, Baltic modernism, 243-253.

19 ŠIUPŠINSKAS - LANKOTS, Collectivist Ideals, 301-320.

20 LAHTI, The 1960s Shopping, 40.

21 ŠIUPŠINSKAS - LANKOTS, Collectivist Ideals, 301-320. 
and mikrorayons of the Baltic States of the Soviet period is available along with a rather comprehensive comparison with the Scandinavian planning models; ${ }^{22}$ however, the problematic issues of shopping centres fail to receive more detailed investigation.

\section{The idea of a Soviet shopping centre: from North to West}

The search for the concept and composition of Soviet shopping centres was carried out through analysis of the Scandinavian and Western practice of urban planning, housing construction and shopping centre development. For Soviet architects, the Scandinavian and Western construction practice of shopping centres was mostly relevant in its composition and architectural dimensions; however, the issue of consumption by capitalist society was eliminated from their horizon being considered ideologically opposite.

As far back as the 1950s, Soviet architects, builders, engineers and other professionals were sent to Scandinavian and some other Western countries to take a look at their experiences of urban planning, residential construction and the planning and construction of public buildings. ${ }^{23}$ In one way or another, the gained knowledge was conveyed via publications intended for architects and urban planners of the USSR.

In 1960, the architects Boris Leonidovich Vasilyev and Georgiy Dmitrivvich Platonov introduced a book on urban planning practices and residential construction in the Scandinavian countries dealing with the new suburban areas, mikrorayons, residential quarters and complexes, public and shopping centres, types of residential houses and apartments in these countries. According to the authors of the book, the enormous housing construction plans and urban planning of the Soviet Union required an analysis of both "home country" and foreign experience, and the experience of the Scandinavian countries was particularly appropriate in this situation due to the similar geographical and climatic conditions. However, as the same authors explain, the practice of foreign urban planning and housing construction was to be evaluated critically:

Blind copying of the Scandinavian construction techniques and composition is unacceptable. It should be borne in mind that construction techniques and composition are chosen only under appropriate climatic and topographic conditions, taking into account the detailed feasibility analysis of the various solutions proposed. Moreover, it goes without saying that some elements of the foreign practice might be partially or totally unacceptable for us due to different social conditions. ${ }^{24}$

Later, a number of ideas were taken from the Scandinavian planning model of residential areas and shopping centres. One of them was the isolation of footpaths from traffic flows in order to enable the residents of mikrorayons to reach shopping centres on foot without crossing arterial roads. ${ }^{25}$

A publication introduced by the Research Institute of Public Buildings of the USSR in 1964 and dedicated to architects and commerce professionals declared that in view

22 METSPALU - HESS, Revisiting the Role, 335-361. LANKOTS -SOOVÄLI, ABC-Centres, 110-113. HESS, Transport in Mikrorayons, 184-204.

23 DRĖMAITE் - PETRULIS - TUTLYTE், Architektūra sovietineje Lietuvoje, 163-164.

24 VASIL'YEV - PLATONOV, Gradostroitel'naya praktika, 4.

25 DRĖMAITÉ - PETRULIS - TUTLYTĖ, Architektūra sovietineje Lietuvoje, 168. 
of the Soviet urban planning structure containing mikrorayons, residential areas and the entire city, a tiered system of public services seemed the most effective with the shopping centres acting as one of the major operational elements of this system. This was one of the first publications that, along with the general organizational requirements of Soviet shopping centres, also introduced design proposals for shopping centres illustrated with foreign examples on the design and construction of shopping centres, mostly of the US, Sweden and Great Britain. ${ }^{26}$

The development direction of Soviet shopping centres was under further consideration by the Soviet authorities; however, interest in the best practices of the development and implementation of Western shopping centres was increasingly great. Having identified the advantages of shopping centres as a new and effective form of public service, the Soviet authorities enabled architects and engineers of the USSR to become acquainted with the details of construction of British, French and American shopping centres and their layout in urban planning structures. ${ }^{27}$ For example, in his analysis of the shopping centres located in Soviet, British, American and French cities, Veniamin Aleksandrovich Butyagin provided a comparison of the solutions related to composition and shopping centre reachability by car, on foot and by public transport. ${ }^{28}$

However, a considerable portion of the materials on foreign shopping centres published in the Soviet Union was censored; therefore, it was mostly the technical and compositional dimensions of the shopping centre analysis that were introduced, cutting off issues concerning the influence had by the shopping centres of these countries on public consumption. ${ }^{29}$ In 1966, a censored version in Russian of Victor Gruen and Larry Smith's book Shopping Towns USA: The Planning of Shopping Centers was introduced in the Soviet Union, adding to it a preface written by the USSR architect Avraam losifovich Urbakh. ${ }^{30}$ The preface in Russian tells that this is a shortened translation of the book as the sections of the book containing a sociological approach to the promotion of consumption of Western society are beyond any criticism. Further, the arguments for this approach, according to the author of the preface, are based on the fact that Soviet readers must be critical of the capitalist nature of US trade and of the American lifestyle and consumption. ${ }^{31}$

A similar censorship practice towards Western publications was applied later as well. In 1982, Nadine Beddington's book Design for Shopping Centres was published, but the Russian translation of the book introduced in 1986 was without the sections of the original book that described the issues related to the financial aspects of the construction of British shopping centres, to the legal and organizational side, and to some points on the operation of shopping centres. Irina Rafilovna Fedoseyeva, the author of the Russian translation's preface, stated that this "does not have any practical significance for us". ${ }^{32}$ In other words, the operational topics of the capitalist system were avoided. Despite the criticism and censorship of the ideas unfavourable to Soviet

26 BOGDANOV et al. Torgovyye tsentry, 3.

27 BUTYAGIN, Planirovka i blogoustroystva, 36. ADAMOVICH et al. Arkhitekturnoye proyektirovaniye, 390-391. SHVIDKOVSKIY, Gradostroitel'naya kul'tura. VASIL'YEV - PLATONOV, Gradostroitel'naya praktika.

28 BUTYAGIN, Planirovka i blogoustroystva,180-183. 
ideology, the books were appreciated by Soviet architects due to that analysis of the planning, architectural and compositional dimensions of shopping centres that was considered acceptable to the Soviet system.

The planning, architectural and compositional dimensions of Western and Scandinavian shopping centres were also investigated in other publications intended for Soviet architects. Butyagin's 1974 book Planirovka i blogoustroystva gorodov discussed the complexities of Soviet shopping centres along with carrying an analysis of planning, engineering and compositional solutions of British, French, American and Swedish shopping centres. After having analysed foreign practice, Butyagin declared that compared to the shopping centres found in the historical downtown areas, the newly constructed shopping centres require particularly sophisticated engineering solutions due to their composition and reachability options. ${ }^{33}$ For this reason, the theory of Soviet architecture also introduced a rather detailed analysis of the differences between American and European shopping centres in the context of urban planning, that is, the development of American shopping centres in suburban areas and the development of European shopping centres in historical downtown areas. ${ }^{34} \mathrm{~A}$ similar model was also realized in the USSR: some shopping centres were planned in historical downtown areas, whereas others were designed in new residential areas.

Although a significant portion of the information available to Soviet architects about the construction of foreign shopping malls was censored, shopping centres developed in the USSR had a similar composition and functionality. Analysis of the construction practices of Western and Scandinavian shopping centres enabled the figuring out of the major types of Soviet shopping centres. Usually, Soviet shopping centres fell into one of two groups. Taking into account the urban territory where shopping centres were constructed, they were grouped by significance into the following: city-wide (shopping centres located in downtown areas) and area-wide or local (shopping centres located in the satellite parts of the city, that is residential areas or mikrorayons). ${ }^{35}$ Area-wide or local shopping centres provided public services for a particular structural unit of the residential zone, that is a residential area, mikrorayon, residential quarter, complex or another unit of the residential zone, whereas city-wide shopping centres constructed in central and historical downtown areas were intended to provide public services to the population of the entire city. ${ }^{36}$ It should be noted that shopping centres of the latter type were designed and constructed only in the megacities of the USSR.

The concept and composition of Soviet shopping centres were similar to those worked out by V. Gruen and Elsie Krummeck in the 1940s, when one building or a complex of buildings contained different types of stores, catering enterprises and community buildings such as a post office, library, child care centre etc. ${ }^{37}$ In the Soviet Union, the idea of a shopping centre as a community hub introduced by Gruen became particularly accepted; therefore, the function as a community hub was especially highlighted along with the function as a shopping centre. For this reason, the construction of Soviet shopping centres followed the aforesaid concept, and one

33 BUTYAGIN, Planirovka i blogoustroystva.

34 ADAMOVICH et al. Arkhitekturnoye proyektirovaniye, 390-391.

35 BUTYAGIN, Planirovka i blogoustroystva, 174.

36 BOGDANOV et al. Torgovyye tsentry. BUTYAGIN, Planirovka iblogoustroystva, 151-153. ORLOV et al. Magaziny, 107.

37 GRUENBAUM - KRUMMECK, Letter to Ruth, 119. 
centre contained commercial and services establishments, but also other outlets of public services, that is libraries, meeting spaces etc.

Differently from Western shopping centres, the concept and composition of Soviet shopping centres were subject to legislation, without going deeply into the character of a shopping centre (city-wide or local). The "Typization Rules for Retail Enterprises" approved by the Council of Ministers of the USSR on 8 September 1965 specify that both area-wide and city-wide shopping centres may contain food stores and consumer goods shops, catering establishments and public institutions, which may be located in one building or separately arranged buildings. ${ }^{38}$ The work of the architects designing shopping centres was directly affected by the aforesaid rules and actually became an indisputable principle applicable to the design and construction of Soviet shopping centres.

In the design process of Soviet shopping centres, the architects made efforts to integrate into one building or a complex of buildings a range of units such as outlets, cafes, restaurants, bars, household services, post offices, savings banks, pharmacies etc. ${ }^{39}$ The abovementioned shopping centres mostly offered self service, were combined with catering establishments and operated in a single complex with community hubs. ${ }^{40}$ Usually, community hubs contained cultural centres, movie theatres, libraries, dancing and sports halls etc. Actually, the description of such a complex banding together a range of different establishments and outlets was in line with the definition of a shopping centre located in a Soviet mikrorayon or residential area.

City-wide Soviet shopping centres were combined with other large architectural and public complexes, for example hotels, movie theatres, swimming pools, beauty salons, fashion houses, household services etc. ${ }^{41}$

As in the case of the concept or composition, the comparison of definitions of Western and Soviet shopping centres would reveal a range of similarities. Definitions of Western shopping centres were proposed by Geoffrey Baker and Bruno Funaro in the 1950s; as the authors explain, a shopping centre is a combination of department stores, general countryside shops, a commercial block of the downtown area or traditional street market-stall usually owned by one owner, but where the stores are integrated by a particular architectural unit. ${ }^{42}$ Illustrating the concept of a shopping centre, V. Gruen and Larry Smith emphasized its architectural and functional purpose. According to Gruen and Smith, "The shopping center is one of the few new building types created in our time. It also represents one of the rare instances in which a number of individual business enterprises, in banding together, are ready to submit to certain over-all rules in order to further their common welfare." 43

Compared to Western shopping centres, the definition of a Soviet shopping centre was introduced rather late. One of the first attempts was found in the "Provisional Practical Rules for Planning a Retail Chain in Cities" initiated by the Ministry of Commerce of the USSR on 11 March 1966. These rules figured out the definition of

38 Lithuanian Central State Archives (hereinafter LCSA), fond R-772, box 4, file 2748, page 94 (hereinafter, f., b., f., p.).

39 LCSA, f. R-772, b. 4, f. 3348, pp. 188-197.

40 PAJUODIS, Vystyti parduotuvių tinklq, 339.

41 ADAMOVICH et al. Arkhitekturnoye proyektirovaniye, 399. ORLOV et al. Magaziny, 11-125.

42 BAKER - FUNARO, Shopping Centres, 4.

43 GRUEN - SMITH, Shopping Towns USA, 11. 
a shopping centre: it is a complex banding together outlets and catering and household establishments that provide services to the population of mikrorayons, residential areas or the entire city. ${ }^{44}$ Differently from the "Typization Rules for Retail Enterprises" as of 1965, the provisional rules under discussion already introduced the grouping of shopping centres into city-wide and area-wide.

Some time later, a shopping centre definition of a significantly more general character was worked out. In a decree by the Ministry of Commerce of the USSR of 7 October 1972, a shopping centre is defined as a combination of commercial enterprises banded together functionally and spatially in a single complex of buildings that combines outlets and catering establishments, and that may also contain household services and other units of public services. ${ }^{45}$ The main feature common both to Western and Soviet shopping centre definitions is that they cover an architectural combination, a complex that integrates different types of commercial and service enterprises; however, in the case of Soviet shopping centres the issue of ownership is avoided, although the Soviet shopping centres were state-owned in one way or another.

A more intensive process of Soviet urban planning and expansion observed in the 1960 s was followed by a new phase related to an evolution of Soviet shopping spaces and public consumption that began the realization of the key development ideas of Soviet shopping centres supporting the importance of the environment of consumption. To ensure the efficient construction of shopping centres, efforts were made to construct these buildings according to standard project designs with a uniform commercial and services structure as deemed to be required by Soviet planning. The key development ideas of Soviet shopping centres were reflected in the evolution of shopping centres in the LSSR.

\section{The first shopping centres in Soviet Lithuania}

In the LSSR, the preparation of the first standard shopping centre projects was started in the early 1960s, and they were intended for mikrorayons. In 1961, three representative project designs for standard shopping centres in mikrorayons containing commercial, cultural and catering establishments and household services worked out by the architect $A$. Aronas were approved. ${ }^{46}$ Efforts were made to ensure that a shopping centre of a mikrorayon - containing such daily demand establishments as food and vegetable stores, consumer goods shops, culinary outlets, canteens, household and urgent repairs services, hairdressing salons/barbershops and other enterprises - would provide services for a maximum radius of $500 \mathrm{~m}$. In residential areas, a shopping centre with such establishments for non-daily needs as department stores, large grocery stores, movie theatres and other enterprises should provide services for a maximum radius of $1.2-1.5 \mathrm{~km} .{ }^{47}$

In the late 1960s, the construction of commercial buildings meeting the conception and composition of mikrorayon-wide Soviet shopping centres was started in the LSSR. The greatest attention was drawn by the shopping centre "Žirmūnai" (architect A. Aronas) opened in Vilnius in 1969, which was constructed according to one of the standard project designs for shopping centres worked out by the architect. Taking into account

44 LCSA, f. R-772, b. 4, f. 2748, pp. 7-22.

45 LCSA, f. R-772, b. 4, f. 3348, p. 6.

46 LCSA, f. R-545, b. 1, f. 460, pp. 7-9.

47 ARONAS - BALČIŪNAS, Mikrorajony visuomeniniai, 7. 
the fact that it was one of the first shopping centres of this kind, the new building was named as an experimental commercial/household centre. It contained a department store, post office, telephone station, savings bank, grocery store, vegetable store, restaurant, pharmacy, water syphon filling station, hairdressing salon/barbershop, chemical cleaning and dyeing shop, watch repair shop, laundry etc. ${ }^{48}$ According to the architects of that time, the shopping centre under discussion enabled the analysis of advantages and disadvantages of this new type of commercial building as well as the observation of population assessments. ${ }^{49}$ Shortly afterwards, the construction of similar centres was started following Aronas' models in other cities of the LSSR. However, to meet more effectively commercial needs such as an increase in the area of commercial spaces for the laying out of goods in special containers or for the usage of advertising measures, adjustments to the standard designs were often applied..$^{50}$ (Figures 1 and 2)

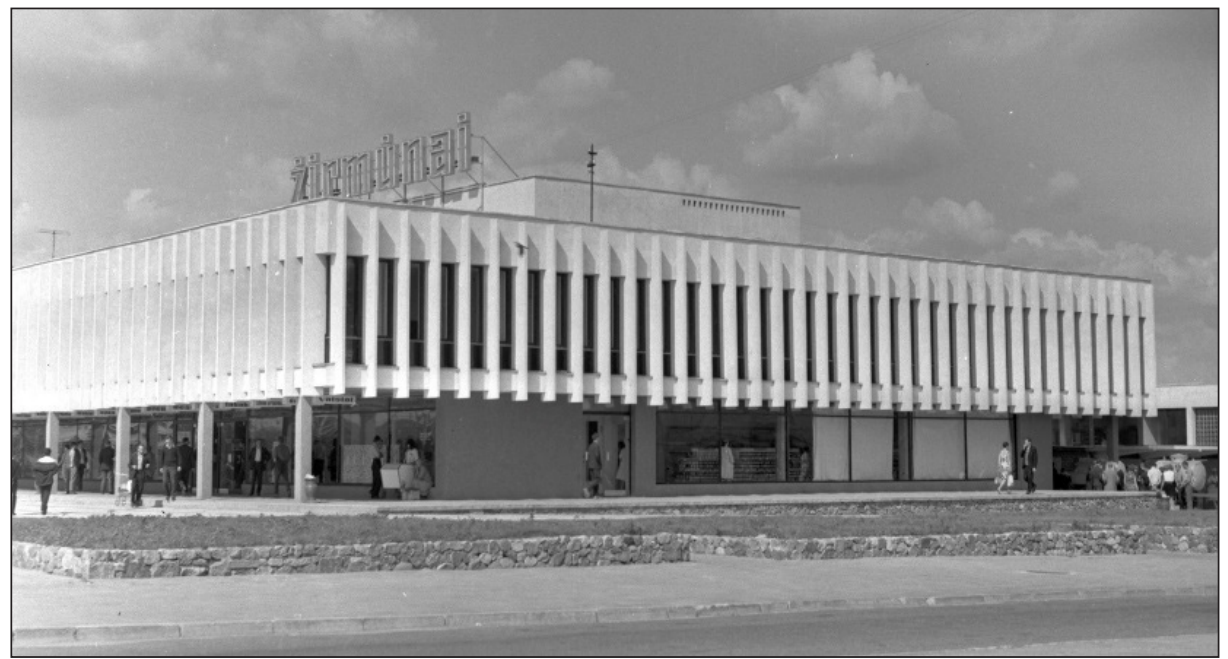

Figure 1: Žirmūnai shopping centre in Vilnius, 1969. Source: Photograph by A. Aleksandravičius. Lithuanian Central State Archives.

48 MEDAISKIS, 'Patogu? Taip, 22.

49 ARONAS - BALČIŪNAS, Mikrorajony visuomeniniai, 8.

50 LCSA, f. R-772, b. 4, f. 3098, pp. 119-120, 184. 


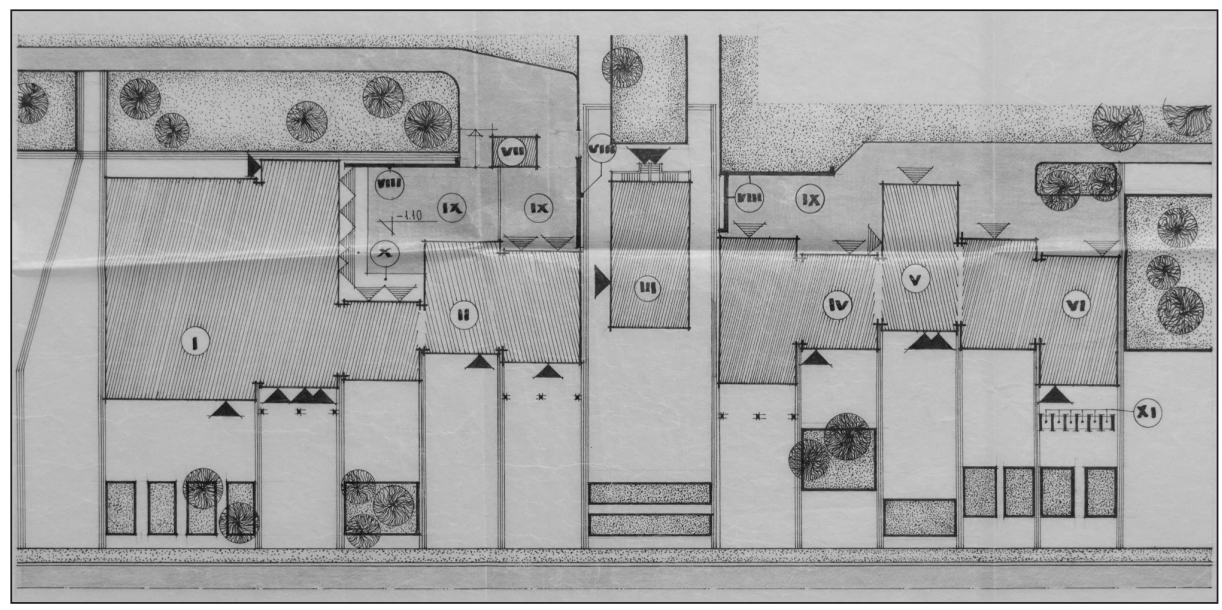

Figure 2: The typical design of the shopping centre, no. 272-31-46, designed by architect $A$. Aronas. Version C. I - Trading block, II - Household service establishment, III - Household services block, IV - Public catering block, V - Pharmacy, VI - Communication department and a savings depository, VII - Transformer room, VIII - Fence, IX - Inner yard, X- Ramps, XI - Telephone booths. Source: Vilnius Regional State Archives.

After approving the second standard project design for shopping centres worked out by Aronas, construction of the building in Panevezžys, the fifth largest city of the LSSR, was started in 1968. Here, the mikrorayon-wide shopping centre named "Stumbras" was built. ${ }^{51}$ In the 1970 s, in mikrorayons of the residential areas of the biggest cities of the LSSR, shopping centres were constructed according to the adjusted standard designs for shopping centres of Aronas already realized in Vilnius and Panevėžys. ${ }^{52}$

In residential areas, the construction of shopping centres started later than in mikrorayons, and some of them were constructed according to individual project designs. In the LSSR, one example of this kind is the shopping centre "Girstupis" (architects V. Dičius and A. Lèckas) constructed in Kaunas in 1975; featuring distinctive architectural and functional solutions, and surpassing the shopping centre Žirmūnai it was considered one of the biggest shopping centres in the Baltic States of that time. In the building complex of Girstupis, commercial, household and public services were successfully integrated. The aforesaid commercial and cultural centre contained two large blocks with a department store located in one and with a cultural and sports complex located in the other, the two interconnected by the narrow unit of a library. ${ }^{53}$ Describing the architectural solution of Girstupis, the architect Algirdas Kapušinskas paid attention to the shopping centre's body of horizontal lines and to the

51 Vilnius Regional State Archives (hereinafter VRSA), f. 1036, b. 11, f. 493.

52 LCSA, f. R-772, b. 4, f. 3098, pp. 119-120, 184.

53 JANKEVIČIENĖ et al. Kauno architektūra, 158. 
monumentality of the cultural hub, the square paved with large slabs and shaped at the shopping centre and the clear layout of the shopping centre offering a good sense of direction for buyers. ${ }^{54}$ (Fig. 3)

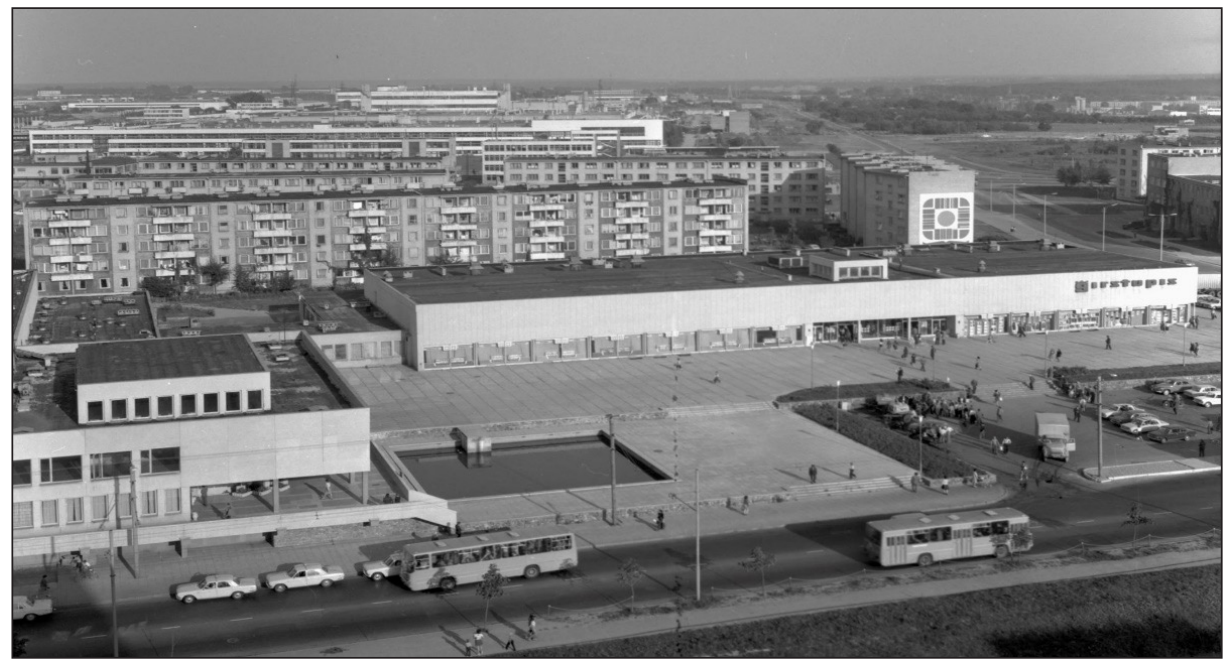

Figure 3: Girstupis shopping centre in Kaunas, 1978. Source: Photograph by T. Žebrauskas. Lithuanian Central State Archives.

Although Girstupis was targeted at providing services to the population of a specific residential area, due to the lack of large shopping centres and department stores still prevailing in the 1970s it became a point of attraction for shoppers of the entire city with ambitions to become a city-wide shopping centre. It should be noted that a shopping centre of this size and functionality was still a rare phenomenon in the commercial system of the LSSR.

Being similar to Girstupis, development of the plan of the shopping centre "Šeškinè" (architects G. Baravykas, G. Dindienè, K. Pempè, G. Ramunis) located in the Šeškinès Residential Area in Vilnius was started in 1976. Similarly to Girstupis, the shopping centre was connected with the community hub. The entire complex of buildings, consisting of eastern and western blocks, was situated on both sides of the street. The complex integrated a department store, two food stores, a movie theatre, a cultural hub, a library, a restaurant, a cafe, a canteen, a bar, household services, a post office, a savings bank, outpatient services, a pharmacy and a radio station. ${ }^{55}$ The shopping centre Šeškinė offered good reachability by footpaths from the whole mikrorayon, and the shopping centre space represented the structure of a downtown area with a range of small outlets and boutiques in order to distribute the flows of buyers evenly. ${ }^{56}$ (Fig. 4)

54 KAPUŠINSKAS, Kaune, ties Girstupiu, 2-5.

55 VRSA, f. 1011, b. 5, f. 377, p. 1.

56 DRĖMAITÉ - PETRULIS - TUTLYTĖ, Architektūra sovietinëje Lietuvoje, 390. 


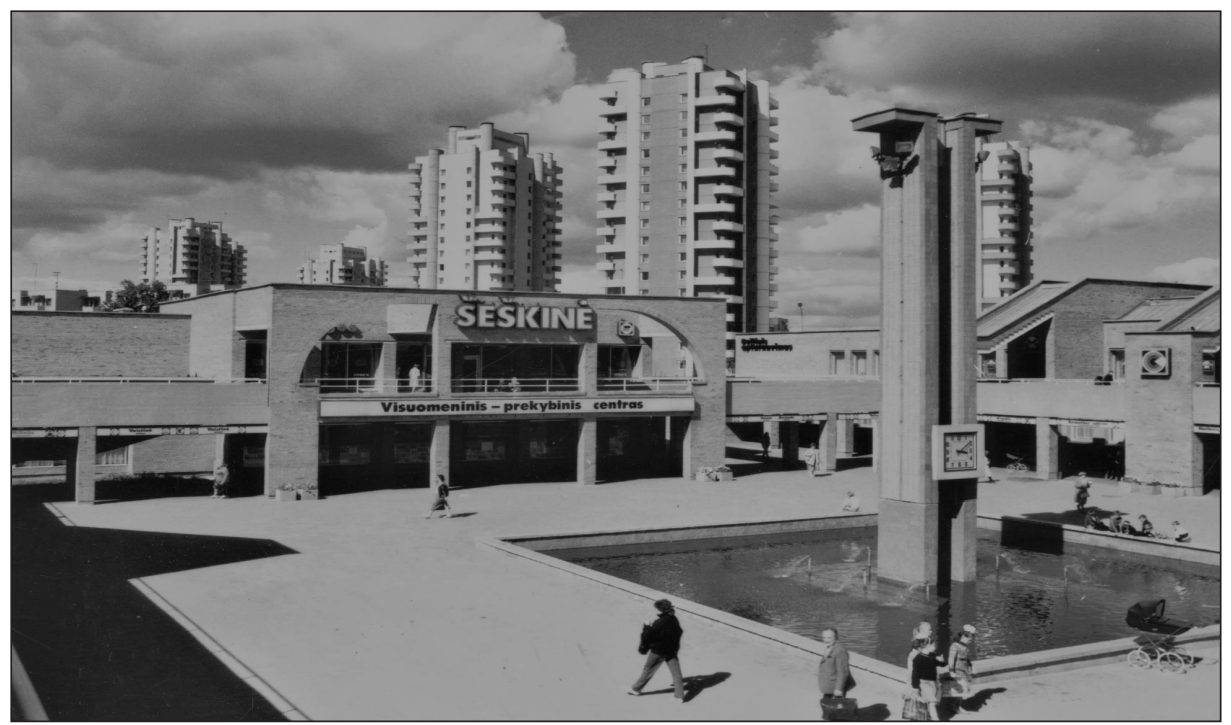

Figure 4: Šeškinė shopping centre in Vilnius, 1985. Source: Author of photograph unknown. Lithuanian Central State Archives.

Differently from other shopping centre designs, the complex of the shopping centre Šeškinè was evaluated critically due to its insufficient links between the eastern and western blocks as they were separated by the street. Another problem was the lack of visual relations and connections between the complex and the square nearby. ${ }^{57}$ Some establishments designed in this shopping centre were never opened, while the realization of the very centre remained incomplete.

In 1986, the shopping centre "Kalniečiai" (architect E. Miliūnas) was opened in Kaunas, becoming the second largest commercial complex in Kaunas after the department store "Merkurijus" situated in the city centre. On the first floor, food stores and stores for non-essential goods were located, whereas consumer goods shops and children's boutiques were arranged throughout two floors. ${ }^{58}$ Window displays and the main exits of the shopping centre overlooked one of the most intensive arterial roads of those times, Raudonosios Armijos avenue (now Savanorių avenue). A greater portion of buildings was designed to sit at one of the most intensive intersections of the residential area, as the densest development of residential housing and the main movement between the largest first and second mikrorayons of the Kalniečių Residential Area was observed here. ${ }^{59}$ Such location of the shopping centre was chosen in order to provide services to the population of a few mikrorayons.

A number of shopping centres situated in residential areas were also designed and constructed in Klaipeda, the third largest city of the LSSR. One of the first shopping

57 Šeškinès visuomeninis prekybos, 20-21.

58 JOKŪBAITIS, Pakvietè Kalniečiai, 1.

59 Kaunas Regional State Archives (hereinafter KRSA), f. R-1702, b. 2, f. 150, p. 8. 
centres, "Aitvaras", located in the Third Residential Area and constructed in the middle of the 1970s, integrated a department store, bookstore, restaurant/cafe, post office with a telephone station, and movie theatre. Later, similar shopping centres of residential areas banding together a range of shops, pharmacies, catering outlets, libraries and other establishments were opened in the Fourth, Fifth and Sixth Residential Areas of Klaipèda. ${ }^{60}$ (Figures 5 and 6)

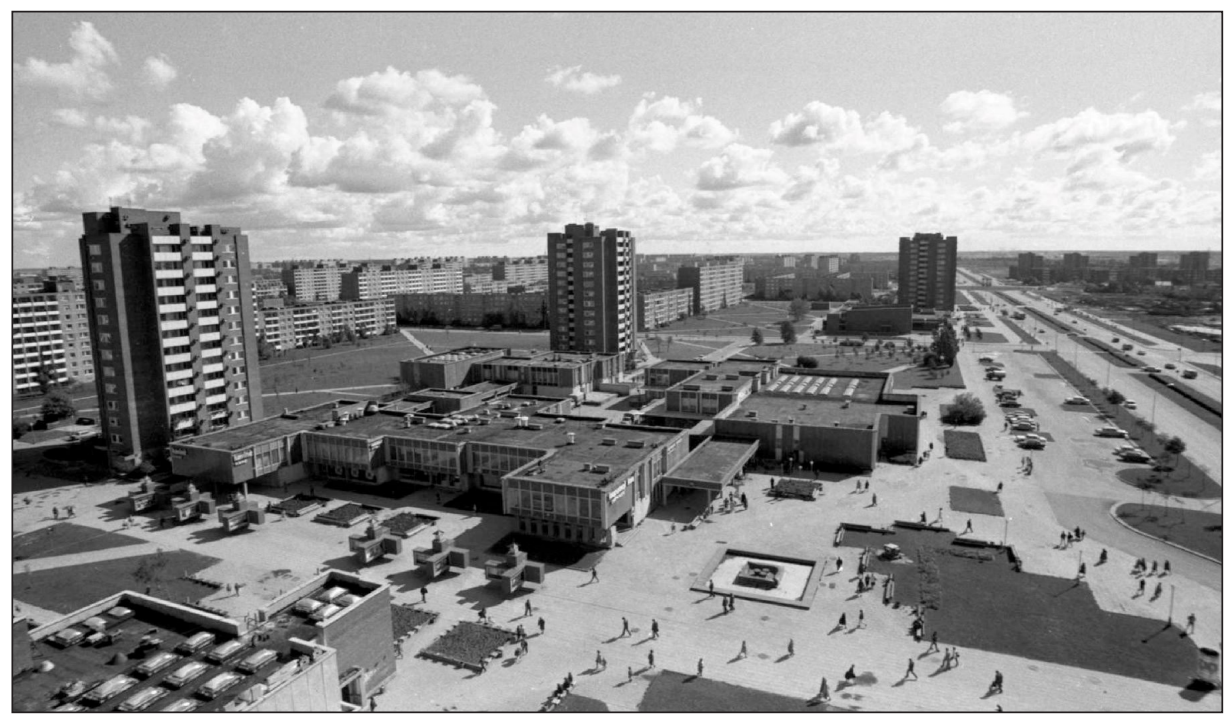

Figure 5: Debrecenas shopping centre in Klaipėda, 1982. Source: Photograph by V. Gulevičius and A. Čiumičiovas. Lithuanian Central State Archives. 


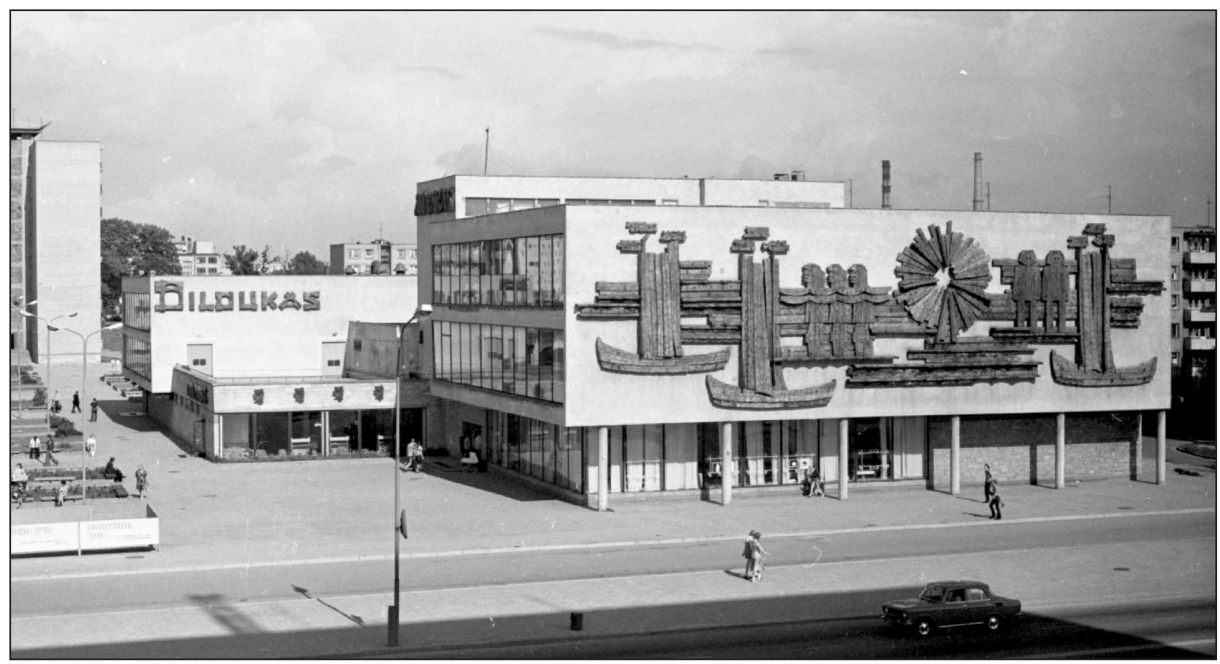

Figure 6: Aitvaras shopping centre and Bildukas restaurant in Klaipėda, 1977. Source: Photograph by A. Ulozevičius. Klaipėda County Public leva Simonaitytė Library.

Actually, no city-wide shopping centres were found in the LSSR; however, such shopping centres as Žirmūnai, Stumbras, Girstupis, Kalniečiai, Šeškinè or Aitvaras having represented the key idea of Soviet shopping centres, that is to provide commercial and household services to settlers of mikrorayons and residential areas, used to extend their scope by their functions, thereby becoming city-wide attractions to the population, as due to the scarce supply of products shoppers were looking for goods in different commercial locations. In each residential area or mikrorayon, at least one shopping centre of a similar composition and functionality was situated. Although the plans for residential areas included more shopping centres with a great range of functions, analysis of the aforementioned sources has demonstrated that the construction of shopping centres was not so rapid as it was supposed to be, and therefore, smaller shops of a different nature were constructed in order to compensate for deficiencies.

It is evident that the idea of Soviet shopping centres was not an original product of the Soviet system. Some aspects of their construction and composition were copied and it was attempted to implement them using Western practice. The Soviet authorities found the idea of Gruen regional shopping centres acceptable and tried to implement it in the newly built city suburbs, as well as to embody the idea of the shopping mall as a multifunctional social centre where social gatherings could be held. Although these ideas were also reflected in the compositions of the LSSR shopping centres, full implementation of the idea of Western shopping centres was problematic in the Soviet system because of the endeavours to control society. This was due to the contraposition to the capitalistic system, the smaller scope of society's modernization, bureaucracy and a lack of materials for construction.

The Soviet shopping centres differed from the Western ones in their accessibility. Contrary to the Western shopping centres directed to the residents with cars living in 
private suburban houses, the Soviet shopping centres were linked to the residential areas, where blocks of apartments were predominant, and few residents had cars.

Nevertheless, along with the emergence of shopping centres in residential areas and mikrorayons, the evolution of an essentially new attitude towards the consumption capacity of the population also occurred, and commercial spaces particularly of this type and respective localization, reachability and composition were chosen for the introduction of the aforesaid attitude.

Analysis of the abovementioned sources reveals that compared to department stores or shops of other types, Soviet shopping centres developed as a place offering at a single location a more diversified range of goods and the complete range of services required by a resident of a city or residential area of that time. The self-service method that emerged with the development of shopping centres empowered shoppers to assess and acquire goods and services independently as well as enabling the application of more goods selling techniques, for instance, advertising.

On the other hand, shopping centres were employed by the Soviet authorities to create the illusion of an abundance of goods, displaying on the shelves articles of the same kind in order to conceal a deficit. ${ }^{61}$ The concealment of the deficit and the development of public consumption affected by propaganda principles had become a significant priority for the Soviet authorities, and Soviet shopping centres were also utilized for this. As the spaces of public services, shopping centres were exploited for the development of the consumption habits of the society, who were supposed to be influenced by propaganda-driven advertising tools used both outside and inside the shopping centres.

\section{Shopping centres as a tool for the formation of consumption}

Shopping centres reflected the process of societal modernization in the case of both capitalistic and Soviet systems. However, that modernization process differed in the area of consumption. ${ }^{62}$ The modernization process of Soviet society was affected negatively by the consumption restrictions and deficits predominant in the totalitarian system, hence making it impossible for society to satisfy their consumption needs, or to satisfy those needs in the shadow market. ${ }^{63}$

To catch up and overtake the consumption standards of Western society was one of the aims in the modernization of Soviet society. However, in the case of the socialist society, the focus was not on quantity but on artificial quality. Therefore, modernization of the socialist society was linked to a consumption culture that had to satisfy criteria established by the authorities such as rationality, abstention from excessive consumption, formation of the Soviet taste etc. ${ }^{64}$ When consumer needs became one of the elements of social modernization, the development of the Soviet industries producing consumer goods became relevant, as well as places and forms of supply of goods, that were manifested through the shopping malls and advertising.

In the 1960s, the literature intended for urban architecture design experts of the USSR declared that the development of Soviet commerce challenged the architects

61 For more information about the advertising of goods as a propaganda tool, see: TRANAVIČIŪTĖ, Soviet Consumer Goods, 111-135.

62 TRANAVIČIŪTĖ, Historical Review, 61-65.

63 TRANAVIČIŪTĖ, Dreaming of the West.

64 TRANAVIČIŪTĖ, Soviet Consumer Goods, 112. 
with the task to work out new advertising types and measures compatible with the architecture of commercial buildings and able to provide comprehensive information about goods, to support the demand and popularity of products, and to form the tastes and culture of buyers. ${ }^{65}$ The aforesaid thought represented the most prominent of the features typifying the architecture of consumption that were supposed to be used in the architectural and advertising designs of the shopping centre to develop the consumption habits of Soviet society on the basis of Soviet propaganda criteria regarding choice of products and quantity of goods.

In Soviet propaganda, the quantity of goods that should be purchased was to be based on a person's perception of the material benefits required to meet their essential needs. The demand for goods was restricted on a moral basis with the aim of eliminating such personal qualities as the desire to possess a lot of things and to boast about them. ${ }^{66}$ Public consumption quantities were defined by criteria covering the main groups of goods, that is foodstuffs, household articles, domestic appliances and furniture, vehicles, goods for vehicle servicing, garages, leisure products, tourism and sports goods, and spiritual and cultural items. From all these groups, around 200 types of goods were considered necessary and fell in line with rational consumption criteria. ${ }^{67}$ Rational consumption criteria were supposed to come under periodic review taking into account economic and social indicators, that is industrial development, production volume, population change, income etc. ${ }^{68}$

In terms of the exploitation of almost identical tools - that is the supply of goods and advertising, huge commercial spaces able to attract buyers by infrastructure, exterior and interior, and the available services and amusement - the development of consumption in the socialist system seemed similar to that in the capitalist system; however, in contrast, the content and development methods of socialist advertising were mostly associated with political propaganda, whereas the actual supply of goods was extremely limited.

If we consider only exterior or interior shopping centre designs in the case of both capitalism and socialism, it would seem that in both cases the main goal was to rationalize consumption and raise the aesthetic level of the consumption experience. However, the two systems of shopping centre designs assigned different functions that were to lead to different trends in public consumption. As Gruen and Smith write in describing shopping centre design, shopping is inherently more than just a utilitarian activity. The slogan "Shopping Should be Fun" has a deep meaning. The environment should be so attractive that customers will enjoy shopping trips, will stay longer and return more often. This will result in cash registers ringing more often and recording higher sales. In regard of the Soviet Union, the slogan "Shopping Should be Fun" should be replaced by "Shopping shouldn't be fun, it should be rational". This meant shoppers had to shop fast, not take long and often not walk to supermarkets. In other words, an attempt was made to eliminate the function of the shopping centre as a place of entertainment.

According to Yelena Dmitriyevna Tverdyukova, Soviet copywriters were forced to refuse the entertainment function in the advertising copywriting process, focusing

65 KOLLI et al. Malyye formy $v$ zastroyke, 130.

66 SINKEVIČIUS, Po vartojimo skraiste, 30.

67 LCSA, f. R-754, b. 4, f. 3322, p. 32.

68 LCSA, f. R-754, b. 4, f. 3322, p. 1. 
on those matters that were considered high living, rational consumption and good taste according to the standards of the Soviet authorities. ${ }^{69}$ In the socialist system, the advertising used on the exterior and interior of commercial buildings was referred to by a few actually synonymous concepts, that is, advertising, agitation, and visual, graphic or aesthetical design measures. ${ }^{70}$ The meaning, however, could be dual: on the one hand, the concepts might be used to characterize direct advertising aimed at promoting consumption; on the other hand, the concepts concealed the material with propaganda content that was employed to develop public consumption on the basis of economic criteria or to praise achievements of the socialist system in urban planning, construction, commerce, public services and other fields.

The theory of the development of Soviet commercial advertising represented the main idea related to the rational consumption and advertising of goods, declaring that such attributes of commercial buildings as signboards, window displays, the compositions available in window displays, and the illumination of those window displays and signboards carry out a guiding function for buyers. ${ }^{11}$ In terms of psychology, the entirety of the outdoor advertising measures of commercial buildings was supposed to affect the way that shoppers start assessing the store from the information signs located above the facades and from their content, which assist them in understanding what goods are available. The window displays of stores were supposed to attract the buyers to take a look at the displayed goods and their properties. As long as the buyers are convinced by the entirety of the visual tools utilized outside, they will come inside and purchase some articles.

Usually, the facades of shopping centres had a few modest signboards with no abundance of advertising measures observed as all expectations to attract buyers were related to the goods displayed in window displays. The signboards and window displays of the commercial buildings mostly carried out a promotional function; however, efforts were made to strengthen the impact made on buyers through the employment of propaganda-based promotional texts of the shopping centres "directing" the buyers to points of attention. The latter were used to conceal the poor diversity of goods, emphasizing the exterior and interior information content of the very shopping centre that assists in guiding the buyers, in the selection of daily goods and fast shopping. For instance, during the presentation of the shopping centre Girstupis, a reporter paid attention to the metal letters "Girstupis" gleaming on the huge building facade from a distance, to the decorated window displays, the amazing size of the shopping centre, and the large commercial spaces divided into sections with tasteful visual signboards above enabling "to see at a glance where shoes are sold and where ties are offered".72 (Figures 7 and 8)

69 TVERDYUKOVA, Sovetskiye reklamnyye tekhnologii, 135.

70 KRSA, f. R-292, b. 2, f. 378, pp. 4-6. KRSA, f. R-292, b. 2, f. 498, pp. 9-11. KRSA, f. R-292, b. 2, f. 681 , p. 8.

71 Preké, reklama, pirkejjas, 4.

72 JURONIS, Kur plonejja piniginè, 2. 


\section{THE Cly' and \\ HISTORY}

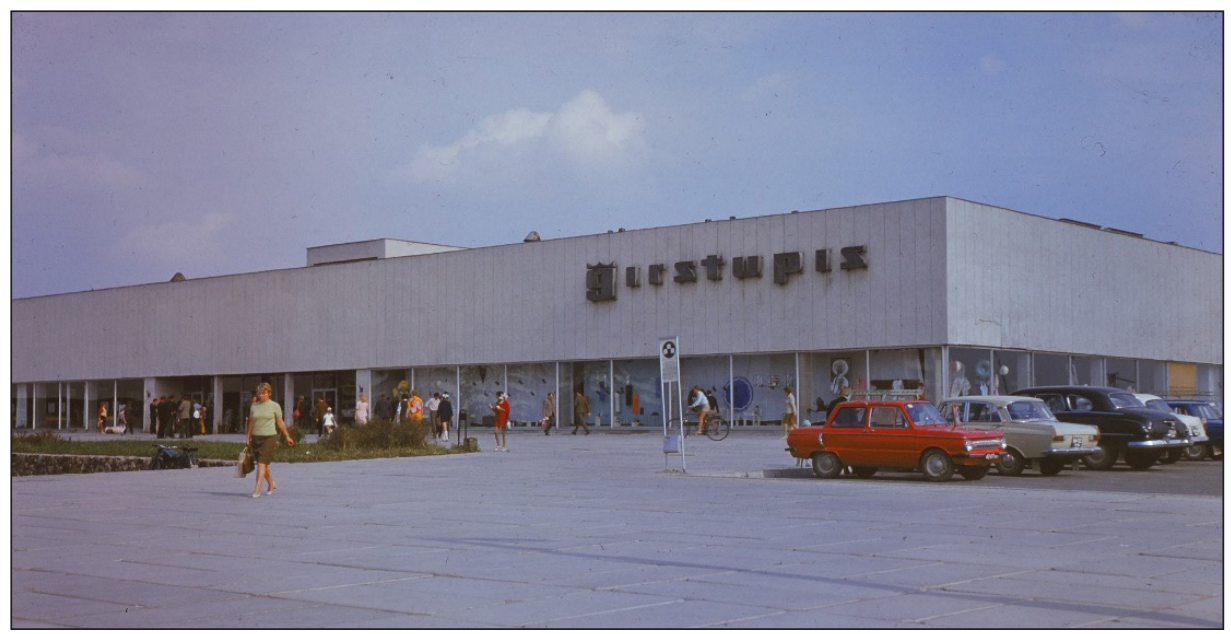

Figure 7: Facade and window displays of the shopping centre Girstupis in Kaunas, 1974. Source: Photograph by S. Lukošius. Kaunas City Museum.

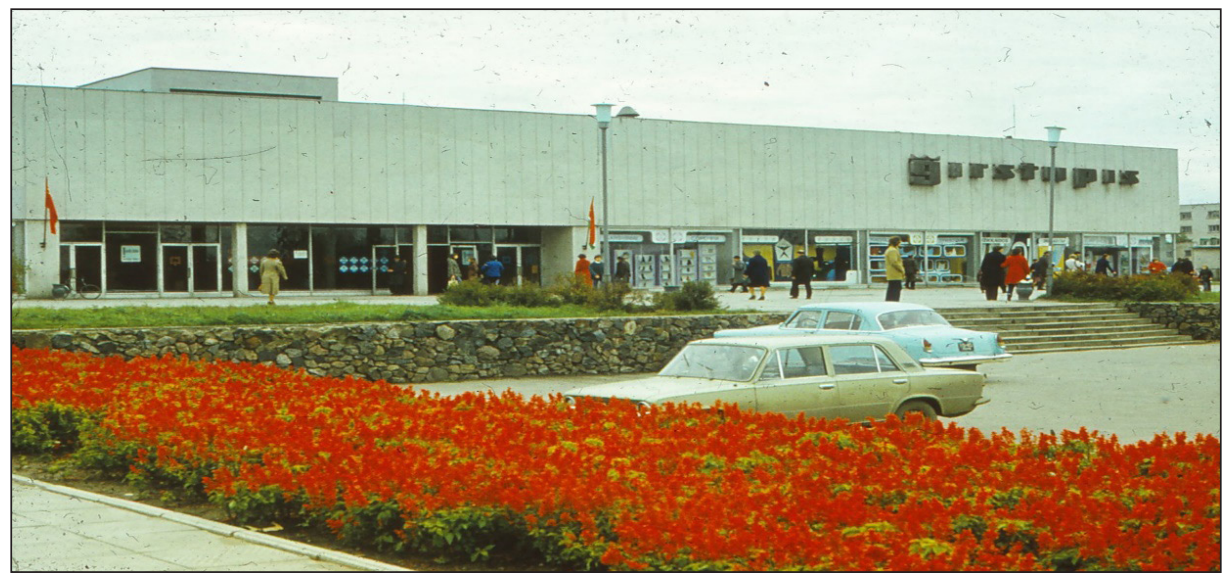

Figure 8: Facade and window displays of the shopping centre Girstupis in Kaunas, 1978. Source: Photograph by S. Lukošius. Kaunas City Museum.

Concerning the absence of advertising on the exterior of shopping centres, attempts were made to explain this situation by the rational advertising used in the interior of the shopping centres that was applied on the grounds of the responsive service of buyers and easing the complexity of the services provided. For instance, the advertising publication of the shopping centre "Vitebskas" located in the Kalniečių Residential Area in Kaunas declared that the "precious time of a buyer is saved by accurate and 
nice information [and] businesslike promotion", ${ }^{73}$ whereas advertising in the shopping centre Šeškinè in Vilnius announced that "functional and quiet advertising enables to move around the shopping space conveniently and to find the required goods easily". ${ }^{74}$ Similar declarations are also found in the description of the interior of the shopping centre "Saulètekis" in Kaunas:

The facade of the shopping centre displays no advertising; therefore, advertising is integrated in the interior. The architectural solution of the building and the character of shopping centre spaces set the mood for the style applied to the interior design. Each space offers a different colour range: blue for foodstuffs, red for consumer goods, yellow for cafe/gastronomy. The advertising is arranged in the following way: at the entrance, a special display panel is available for buyers that helps them to receive information on the layout of commercial spaces. On white advertising strips found in commercial spaces, information on different product groups is provided in a clear and attractive font. "Swinging boards" near the ceiling used for the exposition of goods contribute to a general stylish interior composition. Ensuring the rational use of the area of commercial spaces, "swinging boards" decorated with goods also inform as to the location of different product groups in the commercial spaces. Along with that, clear records on transparent containers and freezing equipment serve well for information communication. The interior is enlivened with black-and-white and coloured slides on faux leather showing the products of individual groups. Prices, promotional panels with product names and cost, branded clothing of salespersons, branded packing paper - it might seem just a detail, but comes as a pleasant surprise to a buyer. ${ }^{75}$

A considerable proportion of the information contained in the promotional leaflets of shopping centres was based on the Soviet propaganda requirements aimed at strengthening the interior impression of the shopping centre, at emphasizing accurate information helping shoppers to move easily in the large spaces and at highlighting the supposed abundance of different goods. (Figures 9 to 11)

73 ŽILEVIČIUS - BRAZAITIS, Kauno miesto prekybos, 3.

74 GRAŽIENĖ, Vilniaus parduotuvès, 1-6.

75 LCSA, f. R-772, b. 4, f. 2601, pp. 102-103. 


\section{THE $\mathbf{d} / \mathbf{y}^{\mathbf{y}}$ and \\ HISTORY}

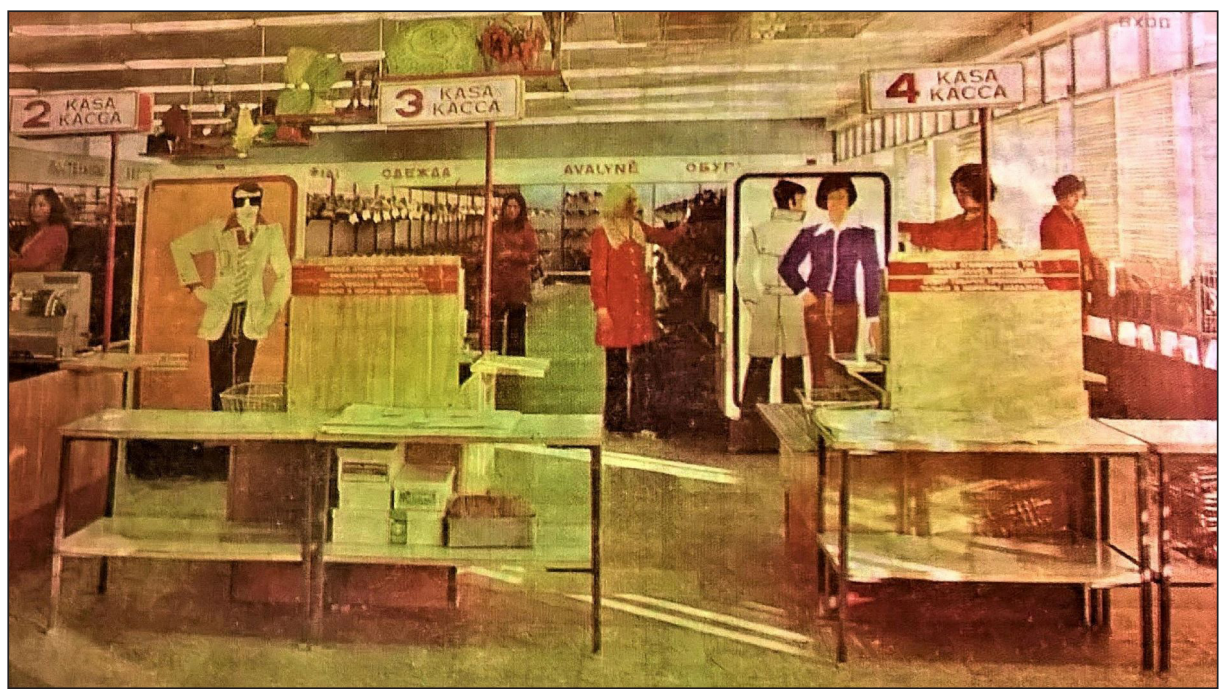

Figure 9: Interior of the shopping centre Sauletekis in Kaunas, 1978.

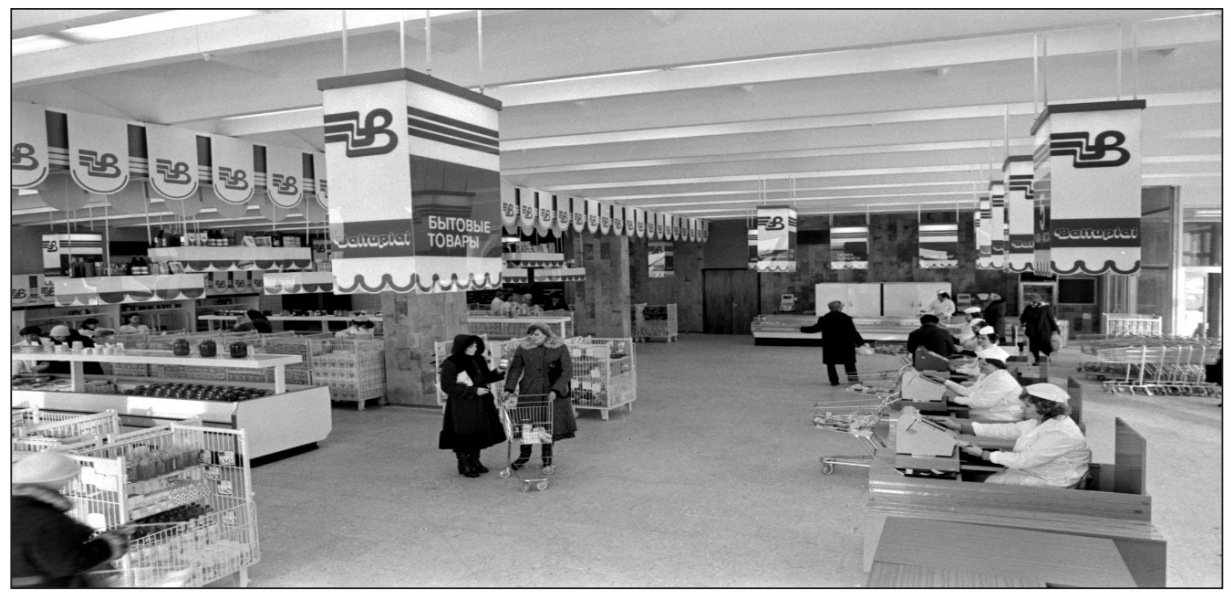

Figure 10: Interior of the shopping centre Baltupiai in Vilnius, 1982. Source: Photograph by A. Sabaliauskas. Lithuanian Central State Archives. 


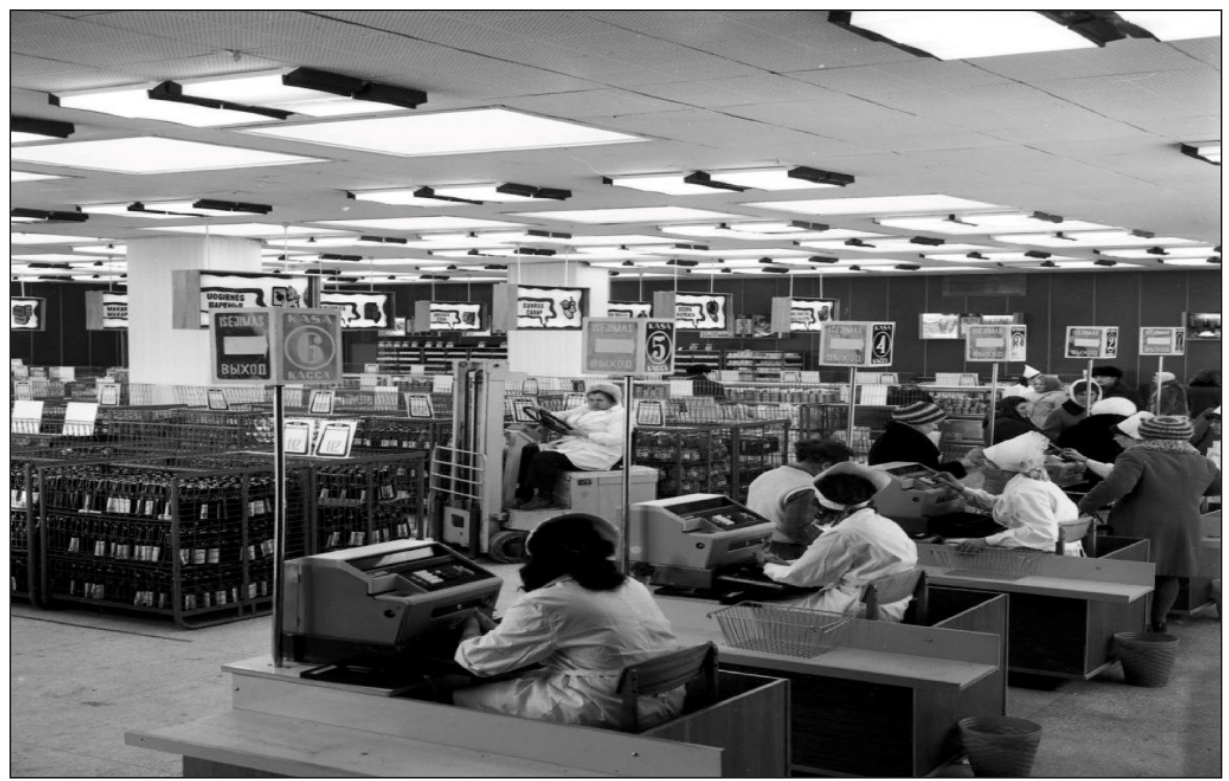

Figure 11: Interior of the shopping centre Debrecenas in Klaipedda, 1974. Source: Photograph by B. Aleknavičius. Klaipėda County Public leva Simonaitytė Library.

The promotional leaflets of shopping centres were also used to enhance the architectural image of shopping complexes as efforts were made by Soviet propaganda to underline the construction achievements of Soviet commercial buildings. In light of the above, instead of introducing the goods available for sale, the promotional leaflets of a range of shopping centres emphasize the vast number of tons of steel and concrete used for the construction of shopping complexes along with the modern finishing materials and the visual design solutions for exteriors and interiors. For instance, "After opening the door of the shopping centre 'Papartis', you will be captivated by the original advertising and characteristic interior with ceramic tiles, laminated panels and organic glass used for its decoration". ${ }^{76}$ In this way, printed information was employed to give a preconceived opinion to buyers about both the goods and the modern style of the very commercial building.

Just through visual assessment of the advertising measures used in the design of Soviet commercial buildings, the difference between the real commercial advertising and the propaganda could not easily be identified by consumers due to the reason that only some of the aforesaid measures were representing the achievements of the Soviet authorities in certain fields in an open manner. Moreover, even the direct advertising of goods or shopping centres was exposed to propaganda requirements that could be known only by the copywriters, they having observed the instructions of the Soviet authorities applied to advertising copywriting. In the theory of development

76 GRAŽIENĖ, Vilniaus parduotuvès, 1-6. 
of advertising, the links between Soviet advertising and political propaganda were declared rather broadly. According to 0 . Snarskiy, a member of the Artists Union of the USSR, Soviet advertising was aimed at addressing economic tasks, at carrying out an information function and at serving as a propaganda tool that contributes to the development of an aesthetical taste and the consumption needs of a Soviet man. ${ }^{77}$

In a general sense, the advertising of commercial buildings was supposed to act in the role of an educator of the communist society. ${ }^{78}$ For example, an artistic installation of window displays at shopping centres was supposed "to aesthetically educate the masses of consumers". ${ }^{79}$ For window displays, the obligations of socialist societal education were assigned by socialist propaganda, the same as for the content of any advertising:

A commercial window display serves a great functional purpose. First of all, it contributes to the image of the city and acts as an indicator of its cultural and economic level and aesthetic taste. At night, an illuminating window display enlivens the urban lights and plays as their integral part. Besides, a window display is one of the key measures of commercial advertising. To buyers, it communicates the character of the shop and a range of goods as well as promoting new products. Theme-based window displays represent fashion, remind of the upcoming season and introduce a socialist household culture. A window display also acts as a political educator. It is a distinctive, continuousaction exhibition of consumer goods introducing the people's economic achievements to the population. ${ }^{80}$

The value of advertising was also associated with the aspirations of Soviet society for higher living standards, technical progress and more effective work. ${ }^{81}$

Similarly to the situation with the development of shopping centres, some commercial advertising technologies of Western countries were also analysed in the formation process of Soviet commercial advertising methods. ${ }^{82}$ Soviet copywriters were enabled to take a look at the advertising copywriting practices applied in France, ${ }^{83}$ Finland, ${ }^{84}$ the USA, ${ }^{85}$ West Germany ${ }^{86}$ and the Socialist Bloc countries. ${ }^{87}$ The greatest focus was made on the analysis of window displays, layout compositions of goods and interiors of shopping centres. However, the consumption aspects of capitalist society were strictly eliminated as the question under discussion or criticism; instead of this, the contraposition between the socialist system and capitalist system was

77 SNARSIKIY, Reklama vokrug nas, 3.

78 KOKAREVAS, Reklamos idejjiškumas, 4.

79 URBONAS - ŠLIKAITĖ, Parduotuvès vitrina, 25.

80 Šiuolaikinès vitrinos, 17.

81 Reklamos reikšmé, 27.

82 ROZHKOV, Reklama sovetskogo perioda.

83 Prekè, reklama, pirkèjas, 28-29.

84 MARKEVIČIUS, Reklama-prekybos šypsena, 3-5.

85 KIBILDAITĖ, Reklamq apmoka, 28-29. Kai kurie reklamos būdai, 32-33.

86 Apie vitrinas, 13.

87 Prekybiné reklama, 18-20. Socialistinių šalių reklamos, 32. LOMEIKA, Moldavu pavyzdžiu, 21-22. I. P., Loterija-prekių reklamos, 25. Kaimo prekybos reklama, 4-5. 
employed for the development of the desired consumption habits of Soviet society. An interview with the LSSR economist S. Razma published in Kooperatininkas in 1963 revealed the differences in the advertising of capitalist and socialist countries though the propaganda contraposition between the capitalist and socialist systems. According to Razma, differently from the capitalist system, advertising in the socialist system encourages rational consumption, educates the population and raises its aesthetic level, allowing the developing of new positive needs and getting rid of negative ones. ${ }^{88}$

Furthermore, the contraposition between socialism and capitalism was employed to highlight the advantages of exterior and interior advertising and the consumption in Soviet shopping centres compared to the priorities of capitalist advertising and consumption. Description of the contraposition by Soviet propaganda was rather colourful:

Window displays of shops are screaming and shouting. Huge discount! Great discount sale! A thick red strikethrough line crosses the old price, whereas bright and large digits mark the new value. No matter that after the "huge" discount the good still remained more expensive than in a smaller outlet located at some distance. The main thing is to draw attention, to attract a buyer. These are the realities of the capitalist world. But this is not so about us. We are more moderate, more modest. Our advertising shall contribute to guiding the buyers rather than misleading them. ${ }^{89}$

Through the contraposition between socialism and capitalism via advertising of shopping centres that, according to Soviet propaganda, was moderate and contributed to the good sense of direction of buyers, consumption habits of Soviet society based on the criteria of moderation, modesty and taste were developed by the Soviet authorities. In Soviet propaganda, this model of consumption was grounded on a person's perception enabling them to realize what material benefits are required to meet their essential needs. The advertising measures used on the exteriors, interiors and window displays of commercial buildings were targeted at the development of a consumption based on socialist principles that were contraposed to the consumerism of capitalist society.

\section{Conclusions}

1. The idea of Soviet shopping centres was developed following the examples of Western shopping malls. As the compositional structure of Western shopping malls seemed acceptable to the Soviet authorities, it was taken over and realized during the construction of Soviet shopping centres. The Soviet authorities were impressed by the idea of a shopping centre as a community hub introduced by V. Gruen, where the function of a community hub was especially highlighted along with the function of a shopping centre. In the Soviet system, however, the public institutions located next to shopping centres were supposed to ensure the control of society, whereas the very commercial buildings were often defined in propaganda literature as public/shopping centres. Due to this, compositional dimensions of Soviet shopping centres were legally regulated; that is, the construction, operational and finishing processes of the abovementioned structures were governed by a wide range of rules

88 Preke, reklama, 1-4.

89 PALIULIS, Kviečiame jisigyti, 30. 
issued by the Soviet authorities and representing Soviet propaganda requirements. Despite the all-embracing state regulation, shopping centres represented a new commercial unit in the Soviet system and marked a new stage in the public services of Soviet society, putting a greater focus on the environment of consumption and the consumption possibilities of the population.

2. The typization of Soviet shopping centres was supposed to serve as a reliable method enabling the efficient provision of commercial services to the population of the mikrorayons and residential areas of Soviet cities. In the 1960s, a few examples of shopping centres developed according to standard project designs that were prepared for the mikrorayons of the cities of the LSSR and constructed later in the major cities of the country. The latter process is well illustrated by the shopping centre Žirmūnai in Vilnius, considered one of the best examples having enabled the architects to assess the functionality of the shopping centre and to modify subsequently the standard designs of shopping centres to meet newly emerging needs. The modification process of standard shopping centres, however, was slow; therefore, the modernization of commercial spaces was sluggish or smaller shops of a different nature were constructed instead of innovative and stylish shopping centres. In the residential areas of the cities, shopping centres were usually constructed according to individual project designs. Such residential area shopping centres as Girstupis in Kaunas or Šeškinè in Vilnius used to appeal beyond the boundaries of their designated residential areas, thereby turning into city-wide attractions for the population.

3. The architectural solutions applied to commercial buildings and advertising measures used on both their exteriors and interiors manifested in an architecture of consumption that was employed to regulate the quantity of consumer purchases: to encourage fast shopping, with a focus on the necessary quantities of necessary goods, thereby avoiding over-purchasing. The advertising design of shopping centres was employed by the Soviet authorities as a tool for the formation of a Soviet culture of consumption in which the consumer was expected to be rational, thereby being different from the culture of consumption of capitalist society. The rationality was grounded on a person's perception enabling them to realize what material benefits are required to meet their essential needs, thereby avoiding overconsumption. For the development of the rationality of consumption of Soviet society, visual design measures and advertising were used which were supposed to be modest from the exterior and were expected to bear an information content in the interior; that is, signboards and information signs of the shopping centre were supposed to invite a buyer to come in and to guide him/her towards the required goods, thereby avoiding impulsive buying. As concerns showcases and other advertising measures displaying goods, they were expected to demonstrate a diversity of products, introducing their function and price. For the justification of the rationality-based Soviet culture of consumption, criticism of the consumption of capitalist society was employed based on propaganda declarations about overconsumption and the misleading advertising that contributes to this excess consumption. 


\section{BIBLIOGRAPHY}

\section{Archival sources}

Kaunas Regional State Archives, R-1702

Kaunas Regional State Archives, R-292

Lithuanian Central State Archives, f. R-545

Lithuanian Central State Archives, R-754

Lithuanian Central State Archives, R-772

Vilnius Regional State Archives, 1011

Vilnius Regional State Archives, 1036

\section{Secondary sources}

ADAMOVICH, V.V. et al. Arkhitekturnoye proyektirovaniye obshchestvennykh zdaniy $i$ sooruzheniy. Moskva: Stroyizdat, 1985.

Apie vitrinas. In: Kooperatininkas, 1975, no. 3.

ARONAS, Aleksandras - BALČIŪNAS, Vytautas. Mikrorajonu visuomeniniai-prekybiniai centrai. In: Statyba ir architektūra, 1969, no. 11.

BAKER, Geoffrey - FUNARO, Bruno. Shopping Centres: Design and Operation. New York: Reinhold Publishing Corporation, 1951.

BOGDANOV, S.N. et al. Torgovyye tsentry: NII obshchestvennykh zdaniy. Moskva: Izdatel'stvo literatury po stroitel'stvu, 1964.

BREDDINGTON, Nadin. Stroitel'stvo torgovykh tsentrov. Moskva: Stroyizdat, 1986.

BUCHLI, Victor. An Archaeology of Socialism. London: Routledge, 2000.

BUTYAGIN, Aleksandrovich Veniamin. Planirovka i blogoustroystva gorodov. Moskva: Stroyizdat, 1974.

BUTKUS, Tomas - SAFRONOVAS, Vasilijus - PETRULIS, Vaidas. Klaipédos urbanistine raida 1945-1990. Vilnius: Vilniaus dailès akademija, 2015.

CHERNYSHOVA, Natalya. Soviet Consumer Culture in the Brezhnev Era. London; New York: Routledge, 2013.

DE GRAZIA, Victoria. Irresistible Empire: America's Advance through Twentieth-Century Europe. Cambridge: Belknap Press for Harvard University Press, 2009.

DRĖMAITĖ, Marija - PETRULIS, Vaidas - TUTLYTĖ, Jūratè. Architektūra sovietinèje Lietuvoje. Vilnius: Vilniaus dailès akademijos leidykla, 2012.

DRĖMAITĖ, Marija. Baltic Modernism: Architecture and Housing in Soviet Lithuania. Berlin: DOM Publishers, 2017.

FITZPATRICK, Sheila. Everyday Stalinism: Ordinary Life in Extraordinary Times: Soviet Russia in the 1930s. New York: Oxford University Press, 1999.

GILLETTE, Jr. Howard. The Evolution of the Planned Shopping Center in Suburb and City. In: Journal of the American Planning Association, 1985, vol. 51, no. 4, pp. 449-460.

GORSUCH, Anne. From Iron Curtain to Silver Screen: Imagining the West in the Krushschev Era. In: GYÖRGY, Peteri (ed.). Imagining the West in Eastern Europe and the Soviet Union.

Pittsburgh: University of Pittsburgh Press, 2010, pp. 153-171.

GOSSEYE, Janina. Collectivity and the Post-war Shopping Centre. In: Lusofona Journal of Architecture and Education, 2013, vol. 8, no. 9, pp. 245-264.

GRAŽIENĖ, D. Vilniaus parduotuvés: reklaminis prospektas. Kaunas: V. Kapsuko-

Mickevičiaus spaustuvè, 1987.

GREGG, Kelly. Conceptualizing the Pedestrian Mall in Post-War North America and Understanding Its Transatlantic Transfer through the Work and Influence of Victor Gruen. In: Planning Perspectives, 2019, vol. 34, no. 4, pp. 551-577.

GRYUN, Victor - SMITH, Larry. Torgovyye tsentry SSHA: planirovka torgovykh tsentrov Moskva: Izdatel'stvo literatury po stroitel'stvu, 1966.

GRUEN, Victor - SMITH, Larry. Shopping Towns USA: The Planning of Shopping Centers. New York: Van Nostrand Reinhold, 1960. 
GRUENBAUM, Victor - KRUMMECK, Elsie. "Letter to Ruth Goodhue", Architectural Forum, 16 February 1943. Cited in: MENNEL, Timothy. Victor Gruen and the Construction of Cold War Utopias. In: Journal of Planning History, 2004, vol. 3, no. 2, 116-150.

GUROVA, Olga. Ideology of Consumption in Soviet Union: from Asceticism to the Legitimating of Consumer Goods. In: The Anthropology of East European Review, 2006, vol. 24, no. 2, pp. 92-102.

HANCHETT, W. Thomas. U.S. Tax Policy and the Shopping-Center Boom of the 1950s and 1960s. In: The American Historical Review, 1996, vol. 101, no. 4, pp. 1082-1110.

HARDWICK, M. Jeffrey. Mall Maker: Victor Gruen, Architect of an American Dream. Philadelphia: University of Pennsylvania Press, 2003.

HESLLER, Julie. A Social History of Soviet Trade: Trade Policy, Retail Practices, and Consumption, 1917-1953. New Jersey: Princeton University Press, 2004.

HESS, Baldwin Daniel. Transport in Mikrorayons: Accessibility and Proximity to Centrally Planned Residential Districts during the Socialist Era, 1957-1989. In: Journal of Planning Perspectives, 2018, vol. 17, no. 3, pp. 184-204.

I. P. Reklama, vartotojas ir jo teisè. In: Kooperatininkas, 1974, no. 9.

I.P. Loterija-prekiu reklamos forma. In: Kooperatininkas, 1974, no. 8.

JANKEVIČIENĖ, Algè - LEVANDAUSKAS, Vytautas - MIŠKINIS, Algimantas -

MINKEVIČIUS, Jonas. Kauno architektūra. Vilnius: Mokslas, 1991.

JESSEN, Ralph - LANGER, Lydia (eds). Transformations of Retailing in Europe after 1945.

Farnham: Ashgate, 2012.

JOKŪBAITIS, S. Pakvietė Kalniečiai. In: Kauno tiesa, 1986 (4 June).

JURONIS, L. Kur plonèja piniginè. In: Švyturys, 1971, no. 20.

Kai kurie reklamos būdai. In: Kooperatininkas, 1970, no. 3.

Kaimo prekybos reklama Lenkijos liaudies respublikoje. In: Kooperatininkas, 1972, no. 7.

KAPUŠINSKAS, A. Kaune, ties Girstupiu. In: Statyba ir architektūra, 1971, no. 12.

KIBILDAITE, M. Reklama apmoka pirkèjas. In: Kooperatininkas, 1974, no. 2.

KOKAREVAS, I. Reklamos idejjiškumas. In: Kooperatininkas, 1973, no. 11.

KOLLI, N. YA. - ARTAMONOV, V. A. - TARASOVA, Ye. A. - TOLSTOY, I. A. (eds). Malyye formy $v$ zastroyke $i$ blagoustroystve gorodov. Moskva: Izdatel'stvo literatury po stroitel'stvu, 1964.

LAHTI, Juliana. The 1960s Shopping Centre Grid of Helsinki: A Framework for Future Development. In: GOSSEYE, Janina - AVERMAETE, Tom (eds). Shopping Towns Europe: Commercial Collectivity and the Architecture of the Shopping Centre. London: Bloomsbury Visual Arts, 2017, pp. 38-51.

LANKOTS, Epp - SOOVÄLI, Helen. ABC-Centres and Identities of Mustamäe Mikrorayons. In: Kunstiteaduslikke Uurimusi, 2008, vol. 17, no. 4, pp. 110-113.

LOMEIKA, K. Algis. Moldavu pavyzdžiu. In: Kooperatininkas, 1977, no. 8.

LONGSTRETH, Richard. City Center to Regional Mall: Architecture, the Automobile, and Retailing in Los Angeles, 1920-1950. Cambridge: The Mit Press, 1998.

LONGSTRETH, Richard. Southdale Center. In: LEPIK, Andres - BADER, Vera Simone (eds). World of the Malls: Architecture of Consumption. Berlin: Hatje Cantz, 2016, pp. 43-56.

LONGSTRETH, Richard. The Drive-In, the Supermarket, and the Transformation of Commercial Space in Los Angeles, 1914-1941. Cambridge: The Mit Press, 1999.

MACK, Jennifer. Hello, Consumer! Skärholmen Centre from the Million Program to the Mall. In: GOSSEYE, Janina - AVERMAETE, Tom (eds). Shopping Towns Europe: Commercial Collectivity and the Architecture of the Shopping Centre. London: Bloomsbury, 2017, pp.122137.

MALHEREK, Joseph. Shopping Malls and Social Democracy: Victor Gruen's Postwar Campaign for Conscientious Consumption in American Suburbia. In: LOGEMANN, Jan CROSS, Gary - KÖHLER, Ingo (eds). Consumer Engineering, 1920s-1970s: Worlds of Consumption. London: Palgrave Macmillan, 2019.

MARKEVIČIUS, A. Reklama-prekybos šypsena. In: Kooperatininkas, 1966, no. 8. 
MATIJEVIĆ BARČOT, Sanja - GRIĆ, Ana. Shopping as a Part of a Political Agenda: The Emergence and Development of the Shopping Centre in Socialist Croatia, 1960-1980. In: GOSSEYE, Janina - AVERMAETE, Tom (eds). Shopping Towns Europe: Commercial Collectivity and the Architecture of the Shopping Centre. London: Bloomsbury Visual Arts, 2017, pp. 155-167.

MEDAISKIS, S. Patogu? Taip. In: Buitis, 1969, no. 5.

MENNEL, Timothy. Victor Gruen and the Construction of Cold War Utopias. In: Journal of Planning History, 2004, vol. 3, no. 2, pp. 116-150.

METSPALU, Pille - HESS, Baldwin Daniel. Revisiting the Role of Architects in Planning Large-Scale Housing in the USSR: The Birth of Socialist Residential Districts in Tallinn, Estonia, 1957-1979. In: Planning Perspectives, 2018, vol. 33, no. 3, pp. 335-361.

ORLOV, A.M. et al. Magaziny. Moskva: Stroyizdat 1979.

PAJUODIS, A. Vystyti parduotuviu tinkla. In: Liaudies ūkis, 1962, no. 11.

PALIULIS, Ž. Kviečiame isigyti. In: Kooperatininkas, 1984, no. 7.

PEACOCK, Margaret. Cold War Consumption and the Marketing of Childhood in the Soviet Union and the United States, 1950-1960. In: Journal of Historical Research in Marketing, 2016, vol. 8, no. 1, pp. 83-98.

Prekè, reklama, pirkejjas. In: Kooperatininkas, 1963, no. 9.

Prekybinè reklama: socialistiniu šaliu reklaminiu žurnalu puslapiuose. In: Kooperatininkas, 1963 , no. 5 .

REID, E. Susan. Cold War in the Kitchen: Gender and the de-Stalinization of Consumer Taste in the Soviet Union under Khrushchev. In: Slavic Review, 2002, vol. 61, no. 2, pp. 211-252.

Reklamos reikšmè. In: Kooperatininkas, 1975, no. 11.

ROZHKOV, Yakovlevich Igor. Reklama sovetskogo perioda: kak eto bylo. In: Nauchnyy zhurnal Moskovskogo gumanitarnogo universiteta, 2007, vol. 2.

SHVIDKOVSKIY, Aleksandrovich Oleg. Gradostroitel'naya kul'tura sotsialisticheskoy Chekhoslovakii. Moskva: Izdatel'stvo Akademii Nauk SSSR, 1963.

SINKEVIČIUS, A. Po vartojimo skraiste. In: Komunistas, 1980, no. 10.

SMILEY, David. Pedestrian Modern: Shopping and American Architecture, 1925-1956.

Minneapolis: University of Minnesota Press, 2013.

SNARSKIY, Vladiromich Oleg. Reklama vokrug nas. Kiyev: Reklama, 1983.

Socialistiniu šaliu reklamos naujovès. In: Kooperatininkas, 1964, no. 1.

Šeškinès visuomeninis prekybos centras: žvilgsnis ị projektavimo ir statybos ateitị. In: Statyba ir architektūra, 1987, no. 11.

Šiuolaikinès vitrinos. In: Kooperatininkas, 1988, no. 5.

ŠIUPŠINSKAS, Matas - LANKOTS, Epp. Collectivist Ideals and Soviet Consumer Spaces: Mikrorayon Commercial Centres in Vilnius, Lithuania and Tallinn, Estonia. In: HESS, Baldwin Daniel - TAMMARU, Tiit (eds). Housing Estates in the Baltic Countries: The Legacy of Central Planning in Estonia, Latvia and Lithuania. Cham: Springer International Publishing, 2019, pp. 301-320.

TRANAVIČIUTTE, Brigita. Dreaming of the West: The Power of the Brand in Soviet Lithuania, 1960s-1980s. In: Business History, 2020, vol. 67, no. 1, pp. 179-195.

TRANAVIČIŪTÉ, Brigita. Historical Review of Modernization of three Lithuanian Cities in 1918-1990. In: Modernization of Public Spaces in Lithuanian Cities: Evolution and Transition. Berlin: Sciendo, 2020, pp. 5-132.

TRANAVIČIŪTĖ, Brigita. Soviet Consumer Goods Advertising: Propaganda and Consumption in the 1950s-1980s in Lithuania. In: Lithuanian Historical Studies, 2018, vol. 22, no. 1, pp. $111-135$.

TVERDYUKOVA, Dmitriyevna Yelena. Sovetskiye reklamnyye tekhnologii perioda pozdnego sotsializma 1965-1990 In: Vestnik Leningradskogo gosudarstvennogo universiteta imeni A. S. Pushkina, 2015, vol. 1, no. 4, pp. 135-146.

URBAKH, Iosifovich Avraam. Obshchestvenno torgovyye tsentry. Moskva: CNTI po Stroitelstvo I Architektury, 1972.

URBAKH, Iosifovich Avraam. Torgovyye zdaniya i kompleksy. Moskva: Stroyizdat, 1974. 
URBONAS, J. - ŠLIKAITĖ, A. Parduotuvès vitrina. In: Kooperatininkas, 1969, no. 10.

VASIL'YEV, Leonidovich Boris - PLATONOV, Dmitrevich Georgy. Gradostroitel'naya praktika $i$ zhilishchnoye stroitel'stvo $v$ skandinavskikh stranakh. Leningrad: Stroyizdat, 1960.

WALL, Alex. Victor Gruen: From Urban Shop to New City. Barcelona: Actar, 2005.

WEITZMAN, Phillip. Soviet Long-Term Consumption Planning: Distribution According to Rational Needs. In: Soviet Studies, 1974, vol. 26, no. 3, pp. 305-321.

ZAKHAROVA, Larissa. Dior in Moscow: A Taste for Luxury in Soviet Fashion Under Krushchev. In: CROWLEY, David - REID, E. Susan (eds). Pleasures in Socialism: Leisure and Luxury in the Eastern Bloc. Evanston: Northwestern University Press, 2010, pp. 95-120.

ZAKHAROVA, Larissa. How and what to Consume: Patterns of Soviet Clothing Consumption in the 1950s and 1960s. In: VIHAVAINEN, Timo - BOGDANOVA, Elena (eds). Communism and Consumerism: The Soviet Alternative to the Affluent Society. Leiden: Brill, 2015, pp. 85-112.

ŽILEVIČIUS, R. - BRAZAITIS, A. Kauno miesto prekybos organizaciju valdyba. Kaunas: V. Kapsuko-Mickevičiaus spaustuvè, 1984. 